\title{
ANALISIS SIKAP ILMIAH SISWA KELAS IV DALAM PEMBELAJARAN IPA DI SDN 1 TERSOBO TAHUN AJARAN 2020/2021
}

\author{
Frizky Rahmadhani ${ }^{1}$, Kartika Chrysti Suryandari ${ }^{2}$, Tri Saptuti Susiani ${ }^{3}$ \\ Universitas Sebelas Maret Surakarta \\ frizkyrahmadhani@student.uns.ac.id
}

\section{Article History}

accepted 30/8/2021

approved 30/9/2021

published 30/10/2021

\begin{abstract}
The research aimed to describe the instillation of scientific attitudes in natural science learning to fourth grade students and to describe the scientific attitudes shown by fourth grade students in natural science learning at SDN 1 Tersobo in academic year of 2021/2021. The research used qualitative method with descriptive approach. Data collection techniques used observation, questionnaires, interviews, and document studies. Data analysis used Miles and Huberman's qualitative data analysis model including data reduction, data presentation, and verification. The results showed that parents and fourth grade teachers had instilled scientific attitudes. The teacher made an attitude assessment in the lesson plan. However, the teacher did not make scientific attitude assessment specifically for natural science learning. The student's attitude scores in report cards were similar including the scores of spiritual attitudes and social attitudes. In natural science learning, most of the students showed the scientific attitude so that student's characters were good. Each aspect in indicators, the scientific attitude had appeared in the students, although some students did not show the scientific attitude.
\end{abstract}

Keywords: scientific attitude, natural science learning, characters

\begin{abstract}
Abstrak
Penelitian ini bertujuan untuk mendeskripsikan penanaman sikap ilmiah dalam pembelajaran IPA pada siswa kelas IV dan mendeskripsikan sikap ilmiah yang ditunjukkan siswa kelas IV dalam pembelajaran IPA di SDN 1 Tersobo tahun ajaran 2021/2021. Penelitian ini menggunakan metode kualitatif dengan pendekatan deskriptif. Pengumpulan data dilaksanakan dengan teknik observasi, angket, wawancara, dan studi dokumen. Analisis data menggunakan model analisis data kualitatif Miles dan Huberman yang meliputi reduksi data, penyajian data, dan verifikasi. Hasil penelitian menunjukkan bahwa penanaman sikap ilmiah dalam pembelajaran IPA sudah ditanamkan dengan baik oleh orang tua dan guru kelas IV. Guru sudah membuat rubrik penilaian sikap dalam RPP. Akan tetapi, guru belum membuat rubrik penilaian sikap ilmiah secara khusus pembelajaran IPA. Nilai raport (sikap) masih secara umum meliputi nilai sikap spiritual dan sikap sosial. Dalam pembelajaran IPA sikap ilmiah sudah ditunjukkan oleh mayoritas siswa sehingga menunjukkan budi pekerti siswa sudah baik. Pada indikator per aspek sikap ilmiah sudah muncul pada diri siswa meskipun masih ada beberapa siswa yang belum menunjukkan sikap ilmiah tersebut.
\end{abstract}

Kata kunci: sikap ilmiah, pembelajaran IPA, budi pekerti 


\section{PENDAHULUAN}

Pendidikan saat ini diharapkan mampu menghasilkan Sumber Daya Manusia (SDM) yang memiliki kemampuan komunikasi dan kolaborasi yang kuat, ahli dalam menggunakan teknologi, keterampilan berpikir kreatif, inovatif serta memiliki kemampuan memecahkan masalah. Berbagai kompetensi yang dibutuhkan oleh peserta didik di era globalisasi saat ini sering disebut juga dengan keterampilan abad $21\left(21^{\text {st }}\right.$ Century Skills) dan konsep pendidikannya lebih dikenal dengan istilah pembelajaran abad 21 (21 $1^{\text {st }}$ Century Learning). Adapun Miller \& Northern (2011: 121) mengemukakan bahwa "Student outcomes include: 1) Core Subjects and 21st Century Themes; 2) Learning and Innovation Skills; 3) Information, Media, and Technology Skills; 4) and Life and Career Skills", yang berarti hasil belajar siswa pada abad 21 meliputi: 1) mata pelajaran inti; 2) keterampilan belajar dan inovasi; 3) keterampilan informasi, media, dan teknologi; 4) dan kehidupan dan keterampilan karir. Pada abad 21 pendidikan menjadi semakin penting untuk menjamin peserta didik memiliki keterampilan belajar dan berinovasi, keterampilan menggunakan teknologi dan media informasi, serta dapat bekerja, dan bertahan dengan menggunakan keterampilan untuk hidup (life skills) (Murti, 2015: 2). Pada dasarnya, kompetensi abad 21 sudah diadaptasi oleh sistem pendidikan di Indonesia melalui Kurikulum 2013. Sikap ilmiah merupakan kecenderungan individu untuk bertindak atau berperilaku dalam memecahkan suatu masalah secara sistematis melalui langkah-langkah ilmiah (Sukaersih, 2011: 79). Dalam menghadapi permasalahan, sikap ilmiah diperlukan agar seseorang tidak gegabah dalam berpikir dan bertindak terutama pada pendidikan dasar yang merupakan fondasi awal dari dasar-dasar diterimanya ilmu pengetahuan.

Pendidikan dasar mempunyai peran yang sangat penting dalam mencerdaskan dan mendewasakan peserta didiknya melalui proses pembelajaran. Pada usia sekolah dasar anak-anak umumnya senang untuk merasakan dan melakukan sesuatu secara langsung. Hal tersebut berhubungan dengan aspek afektif anak-anak usia tersebut. Anak akan bereaksi dengan positif terhadap unsur-unsur yang diterimanya baik unsur baru, tidak layak, aneh atau misterius pada lingkungannya dengan bergerak ke arah benda tersebut, mempermainkannya, atau memeriksanya. Anak sekolah dasar memperlihatkan keinginan untuk lebih mengetahui dirinya sendiri serta senang mengamati lingkungannya untuk mencari pengalaman baru. Hal ini menyatakan bahwa anak usia sekolah dasar berpotensi memiliki sikap ilmiah. Dalam proses pembelajaran, seorang anak didik diharapkan memiliki rasa ingin tahu yang tinggi agar ilmu yang diperoleh berkembang dan bertambah banyak. Guru harus berusaha menanamkan dan menumbuhkan rasa ingin tahu anak didik, terutama anak didik yang pasif dan tidak pernah bertanya. Keingintahuan peserta didik terhadap materi yang diajarkan guru atau dipelajarinya sendiri dapat menyebabkan ilmunya jauh lebih banyak dibandingkan anak didik yang diam dan hanya menunggu penjelasan guru.

Menurut Susanto (2013: 167) IPA (Ilmu Pengetahuan Alam) adalah usaha manusia dalam memahami alam semesta melalui pengamatan yang tepat pada sasaran, serta menggunakan prosedur, dan dijelaskan dengan penalaran sehingga mendapatkan suatu kesimpulan. Pendidikan IPA diharapkan mampu menjadi wahana bagi peserta didik untuk mempelajari alam sekitar dan mampu menerapkannya dalam kehidupan sehari-hari. Pembelajaran IPA di sekolah dasar hendaknya membuka kesempatan untuk memupuk rasa ingin tahu siswa. Dengan begitu, dapat membantu siswa mengembangkan kemampuan bertanya, mencari jawaban atas suatu permasalahan berdasarkan bukti, serta mengembangkan cara berpikir ilmiah (Samatowa, 2011: 2). Proses pembelajaran IPA menekankan pada pengalaman langsung siswa untuk memahami dan menjelajah alam sekitar secara alamiah. Penguasaan konsep hakikat sains diartikan sebagai kemampuan menguasai terhadap produk, proses dan sikap ilmiah yang dikembangkan dalam IPA. Khususnya 
penguasaan oleh siswa terhadap pembelajaran IPA sebagai sebuah kegiatan pembelajaran di kelas (Tursinawati, 2016: 75). Penguasaan konsep hakikat IPA tidak hanya terdiri dari kumpulan pengetahuan atau fakta yang dihafal, namun juga kegiatan atau proses aktif menggunakan pikiran dalam mempelajari rahasia gejala alam. IPA sebagai produk merupakan makna alam dan berbagai fenomena/perilaku/karakteristik yang dikemas menjadi sekumpulan teori dan konsep, hukum, serta prinsip. IPA sebagai proses adalah aktivitas kognitif. IPA sebagai proses akan selalu merujuk pada suatu aktivitas ilmiah yang dilaksanakan oleh para ahli sains. (Toharudin, 2011: 2). IPA sebagai sikap ilmiah adalah penanaman sikap-sikap dalam diri siswa (ilmuwan) ketika melaksanakan proses metode ilmiah (penyelidikan) dan proses pembelajaran IPA (Tursinawati, 2016: 75). Namun, pembelajaran IPA di sekolah dasar sampai saat ini masih terpaku pada paradigma penelusuran informasi dan melupakan aspek lain dari pembelajaran IPA.

Sikap (attitude) adalah istilah yang mencerminkan rasa senang, tidak senang atau perasaan biasa-biasa saja (netral) dari seseorang terhadap sesuatu. "Sesuatu" itu bisa benda, kejadian, situasi, orang-orang atau kelompok orang. Kalau yang timbul terhadap sesuatu itu adalah perasaan senang, maka disebut sikap positif, sedangkan kalau perasaan tak senang disebut sikap negatif. Kalau tidak timbul perasaan apa-apa, berarti sikapnya netral (Sarwono, 2013: 201). Sikap ilmiah merupakan tingkah laku yang didapatkan melalui pemberian contoh-contoh yang positif dan harus dikembangkan supaya bisa dimiliki oleh peserta didik. Tujuan adanya pengembangan dari sikap ilmiah yaitu agar terhindar dari munculnya sikap negatif pada diri peserta didik. Oleh karena itu, sikap ilmiah termasuk aspek yang penting karena berpengaruh pada budi pekerti dan berguna untuk membentuk karakter peserta didik. Beberapa contoh sikap ilmiah yang telah dikenal oleh guru IPA atau guru kelas (untuk jenjang sekolah dasar) yaitu yaitu sikap rasa ingin tahu, jujur, terbuka, toleransi, skeptis, optimis, pemberani, dan kreatif atau swadaya (Jasin, 2011: 45-49). Menurut Harlen (Fatonah dan Prasetyo, 2014: 32-33), sikap ilmiah yang perlu dikembangkan lebih lanjut dalam pembelajaran IPA di sekolah dasar agar bisa dimiliki oleh siswa yaitu: (1) sikap ingin tahu, (2) sikap objektif terhadap data/fakta, (3) sikap berpikir kritis, (4) sikap penemuan dan kreativitas, (5) sikap berpikiran terbuka dan kerjasama, (6) sikap ketekunan, serta (7) sikap peka terhadap lingkungan sekitar.

Peneliti mengamati salah satu sekolah di Kecamatan Prembun pada bulan Oktober 2020, yaitu SDN 1 Tersobo yang sudah menerapkan kurikulum 2013, dimana secara umum proses pembelajarannya berlangsung dengan baik. Sekolah tersebut merupakan salah satu sekolah terbaik di Kecamatan Prembun karena sudah terakreditasi A. Peneliti memilih kelas IV sebagai subjek untuk penelitian karena kelas IV merupakan awal dimulainya kelas tinggi. Hasil wawancara dengan guru kelas IV secara umum pelaksanaan pembelajaran IPA tidak hanya ditekankan pada aspek pengetahuan (kognitif) saja tetapi juga dari aspek sikap (afektif) dan keterampilan (psikomotorik).

Tujuan penelitian ini yaitu untuk mendeskripsikan penanaman sikap ilmiah dalam pembelajaran IPA pada siswa kelas IV dan juga mendeskripsikan sikap ilmiah yang ditunjukkan oleh siswa kelas IV dalam pembelajaran IPA di SDN 1 Tersobo tahun ajaran 2021/2021.

\section{METODE}

Penelitian ini dilaksanakan di kelas IV SD Negeri 1 Tersobo Kecamatan Prembun. Peneliti menggunakan metode kualitatif dengan pendekatan deskriptif. Penelitian ini dilaksanakan selama 2 bulan, mulai bulan Maret hingga bulan Mei 2021. Jumlah subjek penelitian sebanyak 32 siswa kelas IV dengan rentang usia 9-10 tahun. Sumber data penelitian ini yakni guru kelas IV, siswa kelas IV, dan orang tua siswa kelas IV. Teknik pengumpulan data menggunakan teknik observasi, angket, wawancara, dan studi dokumen. Untuk menjamin validitas data dalam penelitian ini 
dilakukan dengan triangulasi sumber dengan membandingkan data hasil observasi, angket, wawancara, dan dokumen. Observasi yang digunakan yaitu observasi partisipasi pasif. Angket yang digunakan yaitu angket terbuka ditujukan untuk orang tua dan siswa kelas IV. Wawancara dilakukan dengan guru kelas IV, siswa, dan orang tua siswa. Kemudian untuk mendukung data tersebut peneliti menggunakan studi dokumen berupa contoh RPP untuk mengetahui nilai sikap yang di nilai utamanya sikap ilmiah dan juga nilai raport siswa terkait aspek sikap untuk mengenali sikap siswa yang telah ditunjukkan pada semester 1 tahun ajaran 2020/2021. Tujuannya untuk mengetahui penyebab terjadinya perbedaan informasi dan untuk memperoleh data hasil pembanding yang dapat berupa kesamaan pendapat atau pemikiran. Analisis data menggunakan model analisis data kualitatif menurt Miles dan Huberman yang meliputi reduksi data, penyajian data, dan verifikasi untuk mendeskripsikan penanaman sikap ilmiah siswa kelas IV dalam pembelajaran IPA dan sikap ilmiah yang ditunjukkan oleh siswa kelas IV dalam pembelajaran IPA di SDN 1 Tersobo tahun ajaran 2020/2021.

\section{HASIL DAN PEMBAHASAN}

\section{Penanaman Sikap IImiah dalam Pembelajaran IPA pada Siswa Kelas IV}

Penanaman sikap ilmiah merupakan cara yang digunakan oleh guru dan orang tua untuk mengajarkan kepada anak tentang sikap-sikap yang harus dimiliki utamanya dalam pembelajaran IPA. Secara umum penanaman sikap ilmiah dalam pembelajaran IPA yang meliputi 8 aspek sudah ditanamkan semuanya oleh orang tua dengan baik. Peneliti dalam mengambil data menggunakan angket untuk orang tua siswa sebanyak 32. Kemudian melaksanakan wawancara sebanyak 9 orang tua siswa dan guru kelas IV. Didapatkan hasil bahwa penanaman yang dilakukan oleh guru dan orang tua siswa sudah ditanamkan dengan baik. Untuk lebih jelasnya dapat dilihat di bawah ini:

\section{a. Orang Tua Siswa Kelas IV}

Berdasarkan hasil angket dan wawancara orang tua sudah menunjukkan penanaman sikap ilmiah dengan baik dan sudah muncul pada semua indikator aspek sikap ilmiah. Hasil penelitian mengenai penanaman sikap ilmiah dalam pembelajaran IPA oleh orang tua dapat dilihat melalui tabel di bawah ini:

Tabel 1. Penanaman Sikap IImiah oleh Orang Tua

\begin{tabular}{cc}
\hline Aspek & Capaian \\
\hline Rasa ingin tahu & Baik \\
Jujur & Baik \\
Terbuka & Baik \\
Toleran & Baik \\
Skeptis & Baik \\
Optimis & Baik \\
Pemberani & Baik \\
Kreatif atau swadaya & Baik \\
\hline
\end{tabular}

Keterangan:

Baik : Terdapat semua indikator penanaman sikap ilmiah

Cukup : Hanya terdapat beberapa indikator penanaman sikap ilmiah

Kurang : Tidak Terdapat semua indikator penanaman sikap ilmiah 
1) Rasa Ingin Tau

Orang tua mengingatkan untuk bisa membagi waktu antara belajar dengan kegiatan yang lain. Jika anak sering mencari informasi terkait materi IPA melalui internet diperbolehkan asalkan mampu menggunakannya dengan bijak. Menurut Akbar (2011: 15) dalam kegiatan belajar perlu adanya pendampingan dari orang tua agar siswa menjadi semangat dalam belajarnya. Senada dengan pendapat tersebut Fajar (2018: 3) mengatakan bahwa bimbingan mutlak diberikan karena mampu mengawasi dan mengetahui segala kekurangan dan kesulitan anak dalam proses belajar. Orang tua membatasi anak agar tidak menggunakan internet setiap waktu, mereka sering menanyakan pada anak materi yang sudah dipelajari.

2) Jujur

Dalam perkembangan sikap dan perilaku anak di sekolah orang tua perlu membekali anak dengan memberikan bimbingan dan perhatian kepada anak sehingga anak memiliki sikap dan perilaku yang baik dan tidak melakukan pelanggaran serta perilaku menyimpang saat berada di lingkungan sekolah (Yanuarius, 2013: 2). Cara orang tua memberikan nasehat pada anak agar tidak membuka internet atau buku saat ulangan harian IPA berlangsung dengan memberi pengertian bahwa menyontek merupakan tindakan tidak terpuji. Peran saat anak belajar yaitu memantau sembari memberikan nasehat untuk mengerjakan sesuai dengan kemampuan. Hal tersebut dilakukan oleh orang tua untuk melatih kemandirian dan mengetahui perkembangan kognitif anak.

3) Terbuka

Orang tua memiliki tanggung jawab untuk mendidik, mengasuh, dan membimbing anak-anaknya untuk mencapai tahapan tertentu yang menghantarkan anak untuk siap dalam kehidupan bermasyarakat (Yunida, 2017: 33). Orang tua lebih ke mengarahkan menanamkan sikap menerima pendapat yang berbeda, akan tetapi jika ada yang kurang tepat sebisa mungkin diarahkan pelan-pelan. Orang tua selalu menanyakan pada anak materi IPA yang telah dipelajari baik yang dirasanya mudah maupun sulit.

4) Toleran

Pada saat orang tua mendampingi anak belajar, agar tidak terlihat memaksakan pendapat yaitu dengan mengarahkan anak untuk memahami dengan membaca ulang kembali materi tersebut dan memberikan contoh dalam kehidupan sehari-hari sesuai dengan materi yang belum dipahami. Anak harus diajarkan untuk bisa menerima perbedaan dengan baik, misalnya untuk menghargai setiap perbedaan yang dimiliki setiap orang serta tidak memaksakan apa yang selalu jadi keinginannya (Ummairoh dan Anjar, 2019: 21). Orang tua selalu memaafkan anak saat anak rewel tidak mau mengikuti pembelajaran. sikap dari orang tua saat anak rewel yang tidak mau mengikuti pembelajaran dengan menasehati secara pelan-pelan pentingnya belajar untuk masa depan.

5) Skeptis

Sebelum menyerahkan hasil ulangan, orang tua mengarahkan anak untuk mengecek jawabannya. Anak akan menyelidiki bukti-bukti yang melatarbelakangi suatu kesimpulan dengan kritis untuk memperoleh data yang menjadi dasar suatu kesimpulan itu dan tidak akan menerimanya tanpa didukung bukti-bukti yang kuat dan 
kebenarannya perlu dicek atau verifikasi (Jasin, 2011: 48). Cara orang tua mengarahkan anak untuk berhati-hati ketika mengerjakan ulangan harian IPA dengan memberi nasehat agar tidak tergesa-gesa saat mengerjakan dan teliti. Melatih agar tidak mudah menerima pendapat tanpa bukti dengan meminta memberikan contoh nyata dalam kehidupan sehari-hari terkait materi yang sudah diajarkan. Misalnya menyebutkan contoh kegiatan sehari-hari yang merupakan gaya dorong.

6) Optimis

Mengarahkan anak untuk rajin belajar di rumah tidak banyak bermain. Pada saat mengalami kendala saat pembelajaran IPA dengan memberi pujian dan hadiah atas pencapaian. Peran orang tua dalam menanamkan rasa percaya diri anak dengan menjadi pendengar yang baik, menunjukkan sikap menghargai, dan memberikan pujian motivasi.

7) Pemberani

Arahan dari orang tua agar anak berani berpendapat ketika guru menanyakan materi yaitu setiap kegiatan pembelajaran baik itu berlangsung melalui google meet maupun whatsapp orang tua mengarahkan supaya aktif bertanya maupun menjawab pertanyaan dari guru. Cara orang tua mengakui kesalahan ketika sedang membimbing anak saat belajar IPA dengan meminta maaf menunjukkan letak kesalahannya kemudian memperbaikinya. Sikap yang ditanamkan kepada siswa sebagai pencari kebenaran yang berani melawan semua ketidakbenaran, penipuan, kepura-puraan, kemunafikan, dan kebatilan yang menghambat kemajuan (Jasin, 2011: 48).

8) Kreatif atau Swadaya

Orang tua pernah mengajak anak untuk melakukan percobaan. Percobaan yang pernah dilakukan yaitu percobaan gaya tarik, gaya dorong, gaya otot. Untuk mendorong anak menjelaskan sesuatu kepada orang tua dengan merayu anak. Saat melakukan percobaan agar kebebasan mengeksplorasi anak muncul orang tua memberi contoh

b. Guru Kelas IV dahulu kemudian anak menirukan sesuai kreativitasnya.

Berdasarkan hasil wawancara guru sudah menunjukkan penanaman sikap ilmiah dengan baik dan sudah muncul pada semua indikator. Hasil penelitian mengenai penanaman sikap ilmiah dalam pembelajaran IPA oleh guru dapat dilihat melalui tabel di bawah ini:

Tabel 2. Penanaman Sikap IImiah oleh Guru Kelas IV

\begin{tabular}{cc}
\hline Aspek & Capaian \\
\hline Rasa ingin tahu & Baik \\
Jujur & Baik \\
Terbuka & Baik \\
Toleran & Baik \\
Skeptis & Baik \\
Optimis & Baik \\
Pemberani & Baik \\
Kreatif atau swadaya & Baik \\
\hline
\end{tabular}

Keterangan:

Baik : Terdapat semua indikator penanaman sikap ilmiah

Cukup : Hanya terdapat beberapa indikator penanaman sikap ilmiah

Kurang : Tidak Terdapat semua indikator penanaman sikap ilmiah 
1) Rasa Ingin Tahu

Guru mengingatkan siswa agar rajin menggali informasi tentang materi IPA dengan menggunakan media power point atau video yang dikirim di grup whatsapp dan juga kegiatan yang dekat dengan siswa contoh mengamati jenis daun berdasarkan tulang. Menumbuhkan rasa ingin tahu melalui media video pembelajaran kemudian memancing dengan pertanyaan. Materi yang membuat rasa ingin tahu siswa menjadi tinggi yaitu gaya, karena macam-macam gaya banyak jenis sehingga menimbulkan rasa ingin tahu menjadi tinggi untuk mencari tahu. Guru sering melatih pemahaman siswa dengan menanyakan materi yang telah diajarkan sebelumnya, guru mengawali pembelajaran dengan apersepsi. Selaras dengan pendapat Carolina (2019: 71) mengatakan bahwa rasa ingin tahu terjadi karena siswa menganggap bahwa sesuatu yang dipelajari merupakan hal yang baru yang harus diketahui untuk menjawab ketidaktahuannya. Sedangkan menurut Silmi dan Kusmarni (2017:232-234) rasa ingin tahu adalah suatu emosi alami yang ada pada dalam diri manusia yang mana adanya keinginan untuk menyelidiki dan mencari tahu lebih dalam mengenai suatu hal yang dipelajarinya.

2) Jujur

Menurut Mukodi dan Afid (2014:81) penanaman karakter jujur adalah tindakan-tindakan yang dilakukan oleh guru kepada peserta didik yang diarahkan pada tercapainya tujuan-tujuan pendidikan karakter yang dapat terwujud dengan upaya penanaman karakter di sekolah. Guru mengingatkan siswa saat ulangan harian IPA berlangsung agar tidak membuka buku maupun internet saat pembelajaran dengan mengingatkan di grup bahwa harus mengerjakan sesuai kemampuan. Langkah tersebut sejauh ini berhasil karena guru sudah memahami karakter. Guru memberikan arahan pada siswa agar tidak menyontek dan bertanya saat ulangan berlangsung dengan memberi soal pilihan ganda secara acak untuk mengantisipasi siswa menyontek teman. Langkah yang diambil jika terdapat siswa yang menyontek yaitu menegur dan menasehati. Untuk situasi pandemi seperti ini maka hanya memberi nasehat tidak boleh menyontek.

3) Terbuka

Cara guru agar siswa terbuka dalam pembelajaran dengan menjalin komunikasi yang baik. Guru memiliki tanggung jawab di sekolah untuk mendidik dan membimbing siswanya untuk menghantarkannya siap dalam kehidupan bermasyarakat (Yunida, 2017: 35). Saat berlangsung diskusi, cara mengajarkan untuk menerima pendapat dengan mendampingi jalan diskusi. Siswa sudah menunjukkan sikap terbuka terbukti pada diskusi kelas melalui google meet siswa bersedia mendengarkan dan menerima masukan, itu terjadi pada semua materi. Setelah selesai pembelajaran guru menanyakan apakah sudah memahami materi yang baru saja dipelajari atau belum. Jika belum ulangi kembali sampai siswa paham.

4) Toleran

Sikap guru jika siswa yang memaksakan pendapat saat diskusi dengan memberi pengertian untuk menghargai pendapat teman dan tidak memaksakan pendapat. Siswa harus diajarkan untuk bisa menerima perbedaan dengan baik, misalnya untuk menghargai setiap perbedaan yang dimiliki setiap orang serta tidak memaksakan apa yang selalu jadi keinginannya (Ummairoh dan Anjar, 2019: 23). Cara 
menghadapi siswa yang tidak memperhatikan penjelasan dengan memberikan penguatan negatif dengan cara diam sebentar dan terkesan acuh tak acuh.

5) Skeptis

Cara guru mengarahkan untuk berhati-hati dalam menggali informasi yaitu setelah selesai pembelajaran mengingatkan untuk mempelajari ulang materi dan menyiapkan materi esok hari dengan membaca materi pada terlebih dahulu. Cara Ibu melatih siswa agar tidak mudah menerima pendapat tanpa bukti yaitu pada saat kegiatan diskusi guru mengajukan pertanyaan, selain itu juga tak lupa mengarahkan untuk menggali informasi dari berbagai sumber, juga bisa belajar melalui lingkungan sekitar.

6) Optimis

Guru merupakan pemberi motivasi di sekolah bagi anak, sehingga diharapkan guru dapat memberikan perhatian dan kasih sayang sepenuhnya kepada siswa di sekolah agar di sekolah siswa memiliki motivasi diri (Yanuarius, 2013: 6). Cara menanamkan rasa percaya diri pada siswa dengan memberikan pertanyaan, jika tidak ada memanggil nama dan memberikan semangat bahwa anak mampu menjawab pertanyaan. Cara yang dilakukan jika terdapat siswa yang merasa kurang bersemangat dengan mendampingi dan mendekati anak apa penyebabnya. Kendala yang dialami dalam membimbing yaitu rasa keberanian masih kurang.

7) Pemberani

Pemberani merupakan sikap yang ditanamkan kepada siswa sebagai pencari kebenaran yang berani melawan semua ketidakbenaran, penipuan, kepura-puraan, kemunafikan, dan kebatilan yang menghambat kemajuan (Jasin, 2011: 48). Cara agar siswa mau berpendapat ketika guru menanyakan materi yaitu mengaitkan materi yang sedang dipelajari dengan lingkungan. Guru pernah melakukan kesalahan ketika pembelajaran IPA berlangsung baik penjelasan materi maupun arahan dan meminta maaf atas kesalahan tersebut pada siswa.

8) Kreatif atau Swadaya

Cara yang dilakukan untuk melatih mengeksplorasi kemampuan dalam pembelajaran IPA dengan menggunakan berbagai metode yang bervariasi seperti metode 5M (Mengamati, Menanya, Menalar, Mencoba, dan Mengomunikasikan). Dalam membentuk anak yang kreatif seorang guru memiliki peranan yang besar, sebab salah satu tugas guru adalah mempengaruhi dan membentuk peserta didik sebagai generasi yang memiliki kreatifitas yang tinggi (Setiawan, 2016: 6). Sebelum pandemi guru pernah melakukan percobaan perambatan bunyi melalui benda padat, benda cair, dan benda gas, kemudian mengamati jenis-jenis daun, membuat cakram warna, percobaan gaya magnet, listrik, dll. Pada masa pandemi hanya melakukan percobaan sederhana, untuk percobaan menggunakan alat tidak dilaksanakan karena kurangnya pendampingan orang tua yang sibuk bekerja.

Peneliti melakukan studi dokumen dengan mengamati RPP yang dibuat oleh guru dapat diketahui bahwa guru belum membuat penilaian sikap ilmiah untuk mata pelajaran IPA masih terfokus pada penilaian sikap secara umum. Guru mengemukakan bahwa penilaian sikap juga tidak langsung dilaksanakan setiap pertemuan. Guru terkadang menilai sikap siswa dengan memberi tanda centang atau memberi nomor pada format penilaiannya. Guru hanya membuat format penilaian sikap, belum 
membuat format penilaian sikap ilmiah. Jenis sikap yang harus dikuasai siswa beserta indikator-indikator yang harus ditunjukkan juga belum dibuat. Dengan demikian, dapat disimpulkan bahwa guru belum membuat format penilaian sikap ilmiah sehingga penilaian terkait sikap ilmiah siswa masih belum dilakukan.

\section{c. Sikap IImiah yang ditunjukkan Siswa dalam Pembelajaran IPA}

Berdasarkan hasil observasi, angket, dan wawancara siswa sudah menunjukkan indikator tiap-tiap aspek sikap ilmiah dengan baik dan sudah ditunjukkan oleh siswa meskipun ada beberapa indikator yang belum muncul pada beberapa aspek sikap ilmiah untuk aspek skeptis dan kreatif atau swadaya.

1) Rasa Ingin Tahu

Untuk meningkatkan rasa ingin tahu, diadakan kegiatan menggali informasi pada materi pelajaran yang diharapkan dapat mengembangkan karakter rasa ingin tahu (Carolina, 2019: 71). Karakter rasa ingin tahu merupakan kemampuan bawaan makhluk hidup yang mewakili kehendak untuk mengetahui hal-hal yang baru dengan tujuan untuk mengembangkan kemampuan peserta didik (Silmi dan Kusmarni, 2017: 51). Siswa pernah menemukan materi yang menarik untuk dipelajari terutama macam-macam gaya. Siswa diam memperhatikan dan mendengarkan ketika guru menjelaskan materi. Siswa aktif bertanya dan menanggapi saat guru sedang menjelaskan materi, apabila guru mengajukan pertanyaan secara individu mereka akan menjawab dengan sungguh-sungguh sesuai pengetahuan yang mereka miliki.

2) Jujur

Siswa perlu dibekali dengan memberikan bimbingan dan perhatian sehingga anak tidak melakukan pelanggaran serta perilaku menyimpang saat berada di lingkungan sekolah (Yanuarius, 2013: 4). Saat ulangan harian berlangsung siswa mengerjakan sendiri, orang tua hanya memantau, akan tetapi karena situasi pandemi pelaksanaan kegiatan belajar mengajar dilaksanakan di rumah sehingga membatasi pengawasan guru maka banyak anak yang membuka buku atau internet untuk memperoleh jawaban. Pada saat kegiatan belajar mengajar berlangsung di sekolah, jika ada siswa yang menyontek pekerjaan teman maka akan menegur kemudian menasehati dan melaporkan pada guru.

3) Terbuka

Siswa merasa senang saat mendapatkan materi baru, materi tentang macam-macam gaya merupakan materi yang siswa senangi karena erat dengan kehidupan siswa dan mereka alami setiap hari. Misalnya membuka pintu rumah, menutup pintu kulkas yang merupakan contoh dari gaya tarik dan juga gaya dorong. Saat diskusi pembelajaran IPA berlangsung siswa pernah berpendapat tetapi pendapatnya kurang tepat yang mereka lakukan ialah memperbaiki jawaban yang belum tepat. Siswa yang memiliki sikap terbuka yang tinggi tidak akan meremehkan materi baru maupun gagasan yang diberikan oleh guru maupun teman-temannya, dia akan menerimanya (Yunida, 2017: 40).

4) Toleran

Siswa harus diajarkan untuk bisa menerima perbedaan dengan baik, misalnya untuk menghargai setiap perbedaan yang dimiliki setiap orang serta tidak memaksakan apa yang selalu jadi keinginannya (Ummairoh dan Anjar, 2019: 23). Selama kegiatan pembelajaran berlangsung pernah ada teman yang berbeda pendapat kemudian sikap siswa menghargai dengan menggali secara bersama-sama kebenarannya, 
tidak memaksakan pendapat karena akan menimbulkan keributan antar teman. Apabila pendapat teman kurang tepat yang siswa lakukan adalah melengkapi.

5) Skeptis

Ketika mengerjakan tugas dengan sungguh-sungguh dan tidak asal-asalan menjawab serta mengecek terlebih dahulu tugas sebelum diserahkan. Siswa jarang bertanya terkait materi yang belum dipahaminya. Hal tersebut karena malu untuk unjuk keberanian.

6) Optimis

Siswa merasa yakin memiliki kemampuan yang lebih baik dibandingkan teman-temannya karena rajin belajar sehingga akan mengasah kemampuan otak dan dorongan motivasi orang tua sehingga membuat rasa percaya diri tumbuh. Siswa yang memiliki sikap optimis yang tinggi akan memandang kesulitan sebagai batu loncatan agar lebih baik (Saputri, 2017: 67). Siswa antusias mengikuti pembelajaran IPA. Hal ini dikarenakan pembelajaran yang diberikan tergolong aktif dengan memberikan materi, tanya jawab, dan soal evaluasi.

7) Pemberani

Pemberani merupakan sikap siswa sebagai pencari kebenaran yang berani melawan semua ketidakbenaran, penipuan, kepura-puraan, kemunafikan, dan kebatilan yang menghambat kemajuan (Jasin, 2011: 48). Siswa berani untuk menyampaikan pendapat kepada teman saat diskusi berlangsung. Siswa tidak malu jika melakukan kesalahan dan diketahui oleh teman-temannya karena merupakan proses belajar dan sudah saling mengenal antar teman.

8) Kreatif atau Swadaya

Siswa tidak pernah secara sengaja menunjukkan laporan tugas IPA yang sama dengan milik teman, akan tetapi jika hal tersebut terjadi akan memaklumi dan menerima yang penting tidak saling menyontek. Dalam membentuk siswa yang kreatif dibutuhkan orang yang sabar dalam membentuk kreativitas anak agar dapat tumbuh dengan baik (Setiawan, 2016: 8). Siswa belum pernah menyarankan percobaan. Hal ini dikarenakan pada saat sebelum pandemi guru aktif melaksanakan kegiatan percobaan, jika pembelajaran online sulit dilaksanakan percobaan karena terkendala ruang dan waktu.

Peneliti melakukan studi dokumen menggunakan nilai raport (nilai sikap) yang diperoleh siswa kelas IV. Nilai sikap tersebut juga masih bersifat umum nilai sikap spiritual dan sikap sosial (santun, peduli, jujur, tanggungjawab, disiplin, dan percaya diri). Nilai tersebut belum merujuk pada nilai sikap ilmiah dalam pembelajaran IPA. Nilai sikap di raport setiap siswa sama karena sudah sistem dari pusat jadi tidak bisa mengubahnya.

\section{SIMPULAN}

Berdasarkan penelitian dan pembahasan yang telah diuraikan, maka dapat disimpulkan bahwa penanaman sikap ilmiah dalam pembelajaran IPA kelas IV yang dilaksanakan oleh guru dan orang tua siswa secara umum dalam melakukan penanaman sikap ilmiah sudah baik. Guru sudah membuat rubrik penilaian sikap dalam RPP. Akan tetapi, guru belum membuat rubrik penilaian sikap ilmiah secara khusus untuk pembelajaran IPA. Selain itu nilai raport siswa terkait nilai sikap juga masih secara umum meliputi nilai sikap spiritual dan sikap sosial. Dalam pembelajaran IPA sikap ilmiah sudah ditunjukkan oleh mayoritas siswa sehingga menujukkan bahwa budi pekerti siswa sudah tumbuh dengan baik. Pada indikator per aspek sikap ilmiah sudah muncul pada diri siswa dengan baik meskipun masih ada beberapa siswa yang belum menunjukkan sikap ilmiah tersebut dalam pembelajaran IPA. 


\section{DAFTAR PUSTAKA}

Akbar, A. (2011). Peran Orang Tua dalam Pendampingan Anak. Bandung: Angkasa.

Carolina, dkk. (2019). Pembentukan Karakter Rasa Ingin Tahu Melalui Kegiatan Literasi. Indonesian Values and Character Education Journal. Vol. 2 (2).

Fajar, P. (2018). Pendampingan Orang Tua dalam Proses Belajar Anak. Skripsi. Bimbingan Konseling. FKIP. Universitas Sanata Dharma Yogyakarta.

Fatonah dan Prasetyo. (2014). Pembelajaran Sains. Yogyakarta: Ombak.

Jasin, M. (2011). Ilmu Alamiah Dasar. Jakarta: Raja Grafindo Persada.

Miller, L. C., \& Northern, T. (2011). 21st Century skills: prepare student for the future. https://eric.ed.gov/?id=EJ921669

Mukodi dan Afid, B. (2014). Pendidikan Anti Korupsi. Yogyakarta: Aura Pustaka.

Samatowa, U. (2011). Pembelajaran IPA di Sekolah Dasar. Jakarta: Indeks Permata Puri Media.

Saputri, S, R. (2017). Peran Guru Dalam Meningkatkan Sikap IImiah Peserta Didik Kelas V-B di MIN Demangan Kota Madiun. Skripsi. PGMI. Fakultas IImu Tarbiyah dan Keguruan. UIN Maulana Malik Ibrahim.

Sarwono. (2013). Pengantar Psikologi Umum. Jakarta: Rajawali Pers.

Setiawan, R. (2016). Menumbuhkan Sikap Kreatif pada Peserta Didik. Jurnal Asia.

Silmi M dan Kusmarni Y. (2017). Menumbuhkan Karakter Rasa Ingin Tahu Siswa Dalam Pembeljaran Sejarah Melalui Media Puzzle. E-journal UPI . http://ejournal.upi.edu/index.php/factum/article/view/9980.

Sukaersih, S. (2011). Analisis Sikap IImiah dan Tanggapan Mahasiswa Terhadap Penerapan Model Pembelajaran Berbasis Praktikum. Jurnal Pendidikan Penelitian, Vol. 28 (1). https://media.neliti.com/media/publications/125934-IDnone.pdf

Susanto, A. (2013). Teori Belajar dan Pembelajaran di Sekolah Dasar. Jakarta: Kencana Prenada Media Group.

Toharudin, U. (2011). Membangun Literasi Sains Peserta Didik. Bandung: Humaniora.

Tursinawati. (2016). Penguasaan Konsep Hakikat Sains Dalam Pelaksanaan Percobaan Pada Pembelajaran IPA di SDN Kota Banda Aceh. Jurnal Pesona Dasar. Vol. 2 (4).

Ummairoh dan Anjar. (2019). Membentuk Sikap Toleransi Anak Melalui Peran Orang Tua di Dusun Sidodadi B Desa Kampung Padang Kecamatan Pangkatan Kabupaten Labuhanbatu. Jurnal Civitas. Vol. 2 (1).

Yanuarius, dkk. (2013). Peran Orang Tua Dan Guru dalam Mengatasi Sikap dan Perilaku Menyimpang Anak (Studi Kasus di SMA Karya Kasih Parindu). Jurnal Pendidikan. Universitas Tanjungpura Pontianak.

Yunida. (2017). Membentuk Sikap Toleransi Anak Melalui Peran Orang Tua di Perum Pemda Way Huwi Kecamatan Jati Agung Lampung Selatan. Skripsi. Bimbingan dan Konseling Islam. FDIK. UIN Raden Intan Lampung. 